\title{
Synthesis and Catalytic Properties of Iron Oxides in the Reaction of Low-Temperature Ozone Decomposition
}

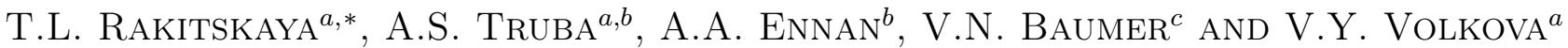 \\ ${ }^{a}$ Faculty of Chemistry, Odessa I.I. Mechnikov National University, 2, Dvoryanskaya Str., 65082, Odessa, Ukraine \\ ${ }^{b}$ Physico-Chemical Institute of Environment and Human' Protection, \\ 3, Preobrazhenskaya Str., 65086, Odessa, Ukraine
}

${ }^{c}$ STC 'Institute for Single Crystals' NAS of Ukraine, 60 Nauky ave., 61001, Kharkiv, Ukraine

\begin{abstract}
Two sets of iron oxide samples were synthesized applying different iron(III) precursors $\left(\mathrm{FeCl}_{3}\right.$ and $\left.\mathrm{Fe}_{2}\left(\mathrm{SO}_{4}\right)_{3}\right)$ and calcination temperature $\left(200,300\right.$, and $\left.500{ }^{\circ} \mathrm{C}\right)$. The samples were characterized by powder X-ray analysis and the Fourier transform infrared spectroscopy. Depending on the synthesis conditions, samples of iron oxides with different phase composition were obtained: polyphase $\left(\alpha-\mathrm{Fe}_{2} \mathrm{O}_{3}, \gamma-\mathrm{Fe}_{2} \mathrm{O}_{3}, \mathrm{Fe}_{3} \mathrm{O}_{4}\right.$, and $\left.\alpha-\mathrm{FeO}(\mathrm{OH})\right)$ and monophase $\left(\gamma-\mathrm{Fe}_{2} \mathrm{O}_{3}\right.$ or $\left.\alpha-\mathrm{Fe}_{2} \mathrm{O}_{3}\right)$ ones. For the samples of homogeneous composition, it has been found that the activity of $\gamma-\mathrm{Fe}_{2} \mathrm{O}_{3}$ in the reaction of ozone decomposition at ozone concentration in gaseous phase of $1 \mathrm{mg} / \mathrm{m}^{3}$ is much higher than the activity of $\alpha-\mathrm{Fe}_{2} \mathrm{O}_{3}$.
\end{abstract}

DOI: 10.12693/APhysPolA.133.1079

PACS/topics: iron oxides, synthesis, thermal treatment, ozone decomposition, catalytic activity

\section{Introduction}

Iron oxides are commonly used in many fields of science and technology [1]. In particular, $\mathrm{Fe}_{3} \mathrm{O}_{4}, \gamma$ - and $\alpha-\mathrm{Fe}_{2} \mathrm{O}_{3}$, as well as $\alpha$ - and $\beta-\mathrm{FeO}(\mathrm{OH})$ are used as catalysts in the case of oxidation of organic compounds with ozone $[2-6]$ and hydrogen peroxide $[7,8]$. Phase compositions of catalysts based on iron oxides depend on an iron salt concentration, the nature of anion and precipitating agent, temperature and duration of hydrolysis, as well as on conditions of drying and calcination of solid precipitates $[1,9-11]$. Catalytic properties of the iron oxide forms with homogeneous phase compositions substantially depend on the nature of surface groups and their ratios $[2,3,12]$, their specific surface, sizes, and shapes of nanoparticles $[1,13]$.

Iron oxides are little-studied in the reaction of ozone decomposition in gaseous phase; however, it was found [14] that $\alpha-\mathrm{Fe}_{2} \mathrm{O}_{3}$ is less active than $\mathrm{MnO}_{2}, \mathrm{NiO}$, or $\mathrm{Co}_{3} \mathrm{O}_{4}$. It is well-known that nanostructured welding aerosols (WAs) contain iron oxide forms such as magnetite, maghemite, hematite, and goethite in various ratios thus influencing the catalytic activity of WAs in the reaction of ozone decomposition $[15,16]$.

The aim of the work was to determine how iron(II, III) precursors and calcination temperature influence the phase composition of iron oxides and their activity in the reaction of ozone decomposition at gaseous phase ozone concentration of $1.0 \mathrm{mg} / \mathrm{m}^{3}$.

\section{Experimental}

Two sets of samples were studied in the work. The samples comprising the first set (IS) were synthesized

*corresponding author; e-mail: tlr@onu.edu.ua from iron(III) chloride and iron(II) sulfate as follows: $46.6 \mathrm{~g}$ of $\mathrm{FeCl}_{3} \cdot 6 \mathrm{H}_{2} \mathrm{O}$ were dissolved in $50 \mathrm{ml}$ of bidistilled water with addition of $2 \mathrm{ml}$ of $3 \mathrm{M} \mathrm{H}_{2} \mathrm{SO}_{4}$. After thorough stirring, $24 \mathrm{~g}$ of $\mathrm{FeSO}_{4} \cdot 6 \mathrm{H}_{2} \mathrm{O}$ were added to the solution. Then, the solution was filtered through a paper filter and its volume was brought to $200 \mathrm{ml}$ by adding bidistilled water. Then, $55 \mathrm{ml}$ of $25 \%$ aqueous solution of $\mathrm{NH}_{3}$ was added to the solution and the resulting reaction mixture was stirred for $1 \mathrm{~h}$. Then, the reaction mixture was kept unstirred for $72 \mathrm{~h}$. A precipitate was washed with bidistilled water until $\mathrm{pH} 6.5-7$ and, after that, was thermally treated at $t=200^{\circ} \mathrm{C}$ (IS-200), $300^{\circ} \mathrm{C}$ (IS-300), or $500{ }^{\circ} \mathrm{C}$ (IS-500).

The samples comprising the second set (IIS) were synthesized from $\mathrm{Fe}_{2}\left(\mathrm{SO}_{4}\right)_{3} \cdot 9 \mathrm{H}_{2} \mathrm{O}(48.4 \mathrm{~g})$ and $\mathrm{FeSO}_{4} \cdot 7 \mathrm{H}_{2} \mathrm{O}$ $(24.0 \mathrm{~g})$ according to the procedure described above. The calcined samples were denoted as IIS-200, IIS-300, and IIS-500.

The samples were investigated by powder X-ray diffraction analysis on a Siemens D500 diffractometer ( $\mathrm{Cu} K_{\alpha}$ radiation, $\lambda=1.54184 \AA$ ) with a secondary beam graphite monochromator. The phases were identified using the ICDD (International Centre for Diffraction Data) PDF-1 databases provided as a part of the Siemens D500 diffractometer software.

Infrared analysis was carried out using a Perkin Elmer FT-IR Spectrometer with resolution of $4 \mathrm{~cm}^{-1}$; pellets consisting of $1 \mathrm{mg}$ of the material under study and $200 \mathrm{mg}$ of $\mathrm{KBr}$ were compressed under pressure of 7 tons $/ \mathrm{cm}^{2}$ for $30 \mathrm{~s}$.

The catalyst samples $(0.5 \mathrm{~g})$ were tested using a gasflow setup with a fixed bed glass reactor at $20^{\circ} \mathrm{C}$, relative humidity of $65 \%$, and the linear velocity $(u)$ of an ozone-air mixture $(\mathrm{OAM})$ equal to $3.2 \mathrm{~cm} / \mathrm{s}$. The ozone decomposition was monitored by measuring the final ozone concentration $\left(C_{\mathrm{O}_{3}}^{f}\right)$. The initial ozone con- 
centration $\left(C_{\mathrm{O}_{3}}^{i n}=1 \mathrm{mg} / \mathrm{m}^{3}\right)$ and $C_{\mathrm{O}_{3}}^{f}$ were measured by a 652EKh04 gas analyzer (Ukraine). The reaction rate $(W)$ calculations based on the change in ozone concentration following OAM passing through the fixed bed of the catalyst were made using the following equation:

$$
W=\frac{w\left(C_{\mathrm{O}_{3}}^{i n}-C_{\mathrm{O}_{3}}^{f}\right)}{m_{\mathrm{s}}}[\mathrm{mol} /(\mathrm{g} \mathrm{s})],
$$

where $w=1.67 \times 10^{-2}$ is the OAM volume flow rate $[\mathrm{l} / \mathrm{s}]$ $C_{\mathrm{O}_{3}}^{i n}$ and $C_{\mathrm{O}_{3}}^{f}$ are the initial and final ozone concentrations in the OAM [mol/l]; $m_{s}$ is the weight of a catalyst sample [g].

The amount of ozone that entered the reaction up to the moment of its half-conversion $\left(Q_{1 / 2}\right.$, moles of $\left.\mathrm{O}_{3}\right)$ was calculated as the area under a corresponding ozonogram plotted as a $\Delta C_{\mathrm{O}_{3}}$ vs. $\tau$ up to $\tau=\tau_{1 / 2}$.

\section{Results and discussion}

$\mathrm{X}$-ray powder patterns for the samples belonging to IS and IIS sets treated at 200,300 , and $500^{\circ} \mathrm{C}$ are shown in Fig. 1.
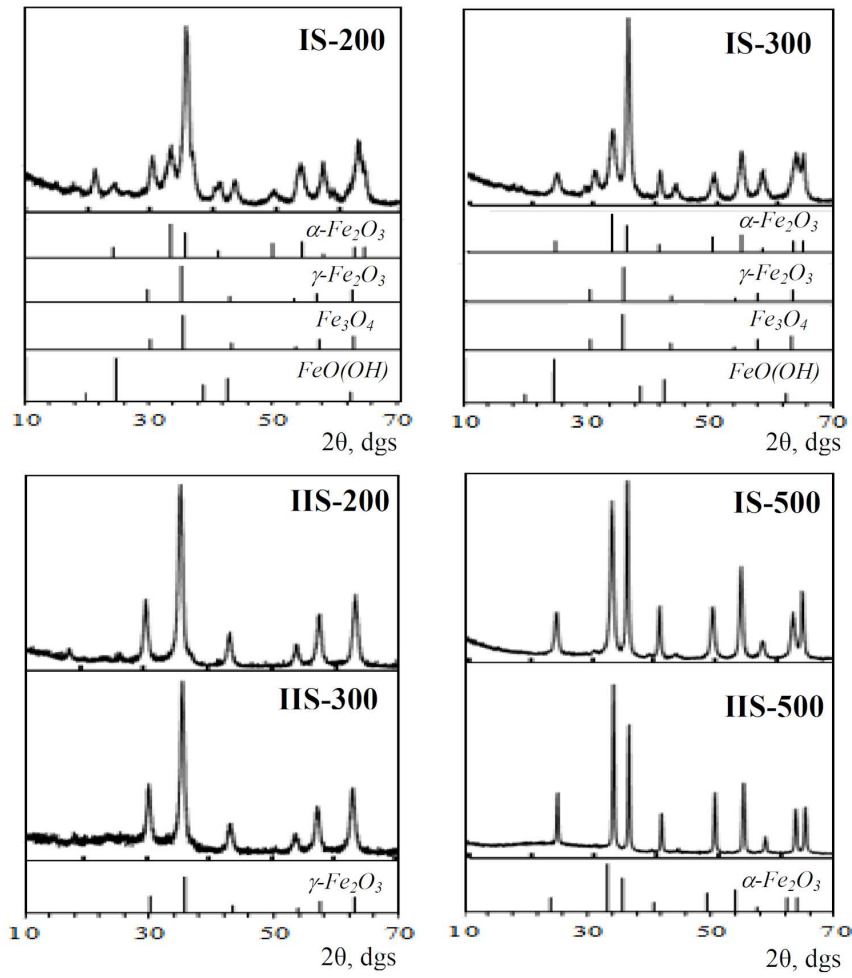

Fig. 1. X-ray diffraction patterns of IS and IIS samples calcined at $200^{\circ} \mathrm{C}, 300^{\circ} \mathrm{C}$, and $500^{\circ} \mathrm{C}$.

The spectra demonstrate that all samples are crystalline; however, the number and positions of reflections as well as their intensities depend on the nature of iron precursors and calcination temperature. The initial search-match procedure let us identify the following phases: hematite, $\alpha-\mathrm{Fe}_{2} \mathrm{O}_{3}$ (JCPDS
33-0664), maghemite, $\gamma-\mathrm{Fe}_{2} \mathrm{O}_{3}$ (JCPDS 39-1346), magnetite, $\mathrm{Fe}_{3} \mathrm{O}_{4}$ (JCPDS 19-0629), and goethite, $\alpha$ $\mathrm{FeO}(\mathrm{OH})$ (JCPDS 29-0713). The quantitative phase analysis for the IS and IIS samples was carried out using the Rietveld method (FullProf program [17]). For each phase, the cell dimensions, line profile parameters, zero correction and background line were refined. Instrumental profile function needed for the size effect evaluation was calculated from $\mathrm{LaB}_{6}$ powder pattern used as an external standard. The initial structure data for the refined phases were taken from the published works [18-21].

From the results of calculations shown in Table I, the following conclusions can be drawn.

IS-200 and IS-300 samples are polyphase. As calcination temperature increases, the contents of $\alpha-\mathrm{Fe}_{2} \mathrm{O}_{3}$ and $\gamma-\mathrm{Fe}_{2} \mathrm{O}_{3}$ phases also increase, whereas the contents of $\mathrm{Fe}_{3} \mathrm{O}_{4}$ and $\alpha-\mathrm{FeO}(\mathrm{OH})$ phases decrease. Thus, the IS-500 sample contains predominantly $\alpha-\mathrm{Fe}_{2} \mathrm{O}_{3}$ phase and $\gamma$ $\mathrm{Fe}_{2} \mathrm{O}_{3}$ impurity phase. The IIS-200 and IIS-300 samples are homogeneous and contain only $\gamma-\mathrm{Fe}_{2} \mathrm{O}_{3}$ phase; however, following calcination at $500{ }^{\circ} \mathrm{C}$, this phase quantitatively transforms into the $\alpha-\mathrm{Fe}_{2} \mathrm{O}_{3}$ phase. The IIS-500 sample diffraction pattern (Table I) closely matches previously published results [1] and reference data [JCPDS $33-0664]$, and all X-ray spectral parameters of $\alpha-\mathrm{Fe}_{2} \mathrm{O}_{3}$ are present. Yet for the IIS-500 sample, unlike for the IIS-200 and IIS-300 samples, the intensity of reflection at $2 \theta=35.653^{\circ}$ is higher than that of $2 \theta=33.161^{\circ}$. This fact can be explained by an overlap of the reflection at $2 \theta=35.653^{\circ}$ with the most intensive reflection of $\gamma-\mathrm{Fe}_{2} \mathrm{O}_{3}$.

The noted above temperature-related decrease in $\mathrm{Fe}_{3} \mathrm{O}_{4}$ phase content and increase in $\gamma-\mathrm{Fe}_{2} \mathrm{O}_{3}$ phase content lead to maximal $\gamma-\mathrm{Fe}_{2} \mathrm{O}_{3}$ presence in the IS-300 sample compared with other IS samples. This confirms the well-known [9, 10, 22, 23] phase transformation chain realized as a result of temperature increase

$$
\mathrm{Fe}_{3} \mathrm{O}_{4} \rightarrow \gamma-\mathrm{Fe}_{2} \mathrm{O}_{3} \rightarrow \alpha-\mathrm{Fe}_{2} \mathrm{O}_{3} .
$$

The observable decline in the $\alpha-\mathrm{FeO}(\mathrm{OH})$ content is due to its transformation that corresponds to the following reaction equation:

$$
2 \mathrm{FeO}(\mathrm{OH}) \rightarrow \alpha-\mathrm{Fe}_{2} \mathrm{O}_{3}+\mathrm{H}_{2} \mathrm{O} .
$$

The parameters of crystal lattice cells for the identified phases coincide with the reference data. Notably, for IS samples, the rise of calcination temperature results in an increase in crystallite sizes of $\alpha-\mathrm{Fe}_{2} \mathrm{O}_{3}$ phase from 6 to $16 \mathrm{~nm}$. The largest size of $\alpha-\mathrm{Fe}_{2} \mathrm{O}_{3}$ crystallites equal to $38 \mathrm{~nm}$ is observed for IIS-500 sample. Crystallite sizes for other phases ranged from 6 to $11 \mathrm{~nm}$.

Thus, the phase composition for iron oxide samples obtained in this work and also sizes of their nanoparticles depend on the nature of iron(III) precursors and calcination temperatures.

Figure 2 shows the Fourier transform infrared (FT-IR) spectra in the region $1000-400 \mathrm{~cm}^{-1}$ for both sets of iron oxide samples. 
Phase composition and phase parameters in the case of iron oxide samples.

TABLE I

\begin{tabular}{|c|c|c|c|c|c|}
\hline Precursor & Sample & Phase & $\begin{array}{c}\text { Phase } \\
\text { content [wt\%] }\end{array}$ & $\begin{array}{c}\text { Cell } \\
\text { dimensions }[\AA]\end{array}$ & $\begin{array}{l}\text { Average apparent } \\
\text { domain size }[\mathrm{nm}]\end{array}$ \\
\hline \multirow{10}{*}{$\mathrm{FeCl}_{3}-\mathrm{FeSO}_{4}$} & \multirow{4}{*}{ IS-200 } & $\alpha-\mathrm{Fe}_{2} \mathrm{O}_{3}$ (hematite) & $56(1)$ & $\begin{array}{l}a=5.0341(6) \\
c=13.780(3)\end{array}$ & 6 \\
\hline & & $\gamma-\mathrm{Fe}_{2} \mathrm{O}_{3}$ (maghemite) & $9.4(5)$ & $a=8.3132(10)$ & 8 \\
\hline & & $\mathrm{Fe}_{3} \mathrm{O}_{4}$ (magnetite) & $19.4(11)$ & $a=8.352(11)$ & 8 \\
\hline & & $\alpha-\mathrm{FeO}(\mathrm{OH})$ (goethite) & $15.2(3)$ & $\begin{array}{l}a=4.6057(10) \\
b=9.953(2) \\
c=3.0090(6)\end{array}$ & 11 \\
\hline & \multirow{4}{*}{ IS-300 } & $\alpha-\mathrm{Fe}_{2} \mathrm{O}_{3}$ (hematite) & $72(1)$ & $\begin{array}{l}a=5.0331(3) \\
c=13.7681(13)\end{array}$ & 9 \\
\hline & & $\gamma-\mathrm{Fe}_{2} \mathrm{O}_{3}$ (maghemite) & $21(1)$ & $a=8.3191(11)$ & 8 \\
\hline & & $\mathrm{Fe}_{3} \mathrm{O}_{4}$ (magnetite) & $4.3(3)$ & $a=8.3556(14)$ & 8 \\
\hline & & $\alpha-\mathrm{FeO}(\mathrm{OH})$ (goethite) & $2.7(4)$ & $\begin{array}{l}a=4.486(9) \\
b=10.10(3) \\
c=3.068(8)\end{array}$ & 11 \\
\hline & \multirow{2}{*}{ IS-500 } & $\alpha-\mathrm{Fe}_{2} \mathrm{O}_{3}$ (hematite) & $98.7(1)$ & $\begin{array}{l}a=5.03250(13) \\
c=13.7532(5)\end{array}$ & 16 \\
\hline & & $\gamma-\mathrm{Fe}_{2} \mathrm{O}_{3}$ (maghemite) & $1.3(1)$ & $a=8.309(2)$ & 11 \\
\hline \multirow{3}{*}{$\mathrm{Fe}_{2}\left(\mathrm{SO}_{4}\right)_{3}-\mathrm{FeSO}_{4}$} & IS-200 & $\gamma-\mathrm{Fe}_{2} \mathrm{O}_{3}$ (maghemite) & $100.0(1.8)$ & $a=8.3424(5)$ & 7.2 \\
\hline & IIS-300 & $\gamma-\mathrm{Fe}_{2} \mathrm{O}_{3}$ (maghemite) & $100.0(1.0)$ & $a=8.3431(7)$ & 7.4 \\
\hline & IIS-500 & $\alpha-\mathrm{Fe}_{2} \mathrm{O}_{3}$ (hematite) & $100.0(5)$ & $\begin{array}{l}a=5.03377(8) \\
c=13.7489(3)\end{array}$ & 38 \\
\hline
\end{tabular}

The spectra were analyzed with regard to the phase compositions of the samples determined by the powder X-ray diffraction (Table I). Absorption bands at 893 and $797 \mathrm{~cm}^{-1}$ typical for a $\mathrm{Fe}-\mathrm{O}-\mathrm{H}$ structural group in $\alpha$ $\mathrm{FeO}(\mathrm{OH})$ phase were present in IS-200 sample, and this is consistent with data obtained by Saric et al. [9]. These bands are absent in FT-IR spectra of IS-300 and IS500 confirming $\alpha-\mathrm{FeO}(\mathrm{OH})$ transformation into $\alpha-\mathrm{Fe}_{2} \mathrm{O}_{3}$ phase. $\alpha-\mathrm{FeO}(\mathrm{OH})$ phase is also absent in IIS samples (Table I) and, accordingly, its bands are absent in their FT-IR spectra. $\gamma-\mathrm{Fe}_{2} \mathrm{O}_{3}$ is present as a main phase in IIS200 and IIS-300 samples and as a secondary phase (9.4 and $21 \mathrm{wt} \%$ ) in IS-200 and IS-300 (Table I). Correspondingly, stretching vibrations of $\mathrm{Fe}-\mathrm{O}$ bond in $\gamma-\mathrm{Fe}_{2} \mathrm{O}_{3}$ are observed in the spectra of the IIS-200 and IIS-300 samples, and are situated at 637,564 , and $444 \mathrm{~cm}^{-1}$ for the former and at 636,562 , and $442 \mathrm{~cm}^{-1}$ for the latter, respectively. These band positions are very close to those reported in literature [24-26]. Due to the overlap of $\mathrm{Fe}-\mathrm{O}$ characteristic bands of several iron oxides, it is difficult to confirm the presence of magnetite in IS-200 and IS300 samples. In almost identical spectra of IS-500 and IIS-500 samples (Fig. 2, curves 3), the presence of bands at 539,455 , and $470 \mathrm{~cm}^{-1}$ typical of $\mathrm{Fe}-\mathrm{O}$ bond confirms the presence of $\alpha-\mathrm{Fe}_{2} \mathrm{O}_{3}$ phase.

The process of ozone decomposition proceeds according to chain-radical mechanism and, therefore, shapes of kinetic curves and the activity of catalysts substantially depend on the ozone initial concentration. We tested the samples obtained at $\mathrm{C}_{\mathrm{O}_{3}}^{i n}=1.0 \mathrm{mg} / \mathrm{m}^{3}$ (Fig. 3) because the influence of chemical and phase composition of the

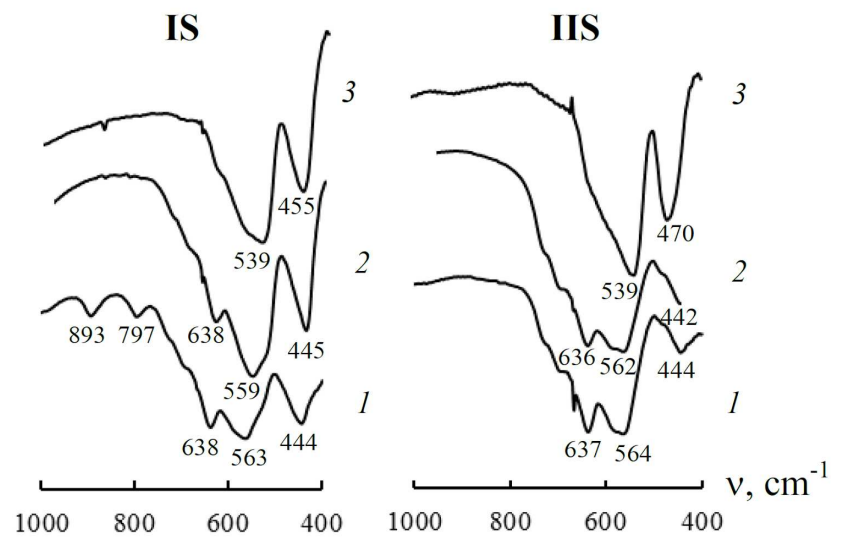

Fig. 2. FT-IR spectra for IS and IIS samples calcined at $200{ }^{\circ} \mathrm{C}(1), 300^{\circ} \mathrm{C}(2)$, and $500{ }^{\circ} \mathrm{C}(3)$.

iron oxide samples on the kinetics of ozone decomposition is more evident at this concentration [15, 16].

Figure 3 shows time dependence of ozone concentration at the reactor outlet, $C_{\mathrm{O}_{3}}^{f}$, for IS and IIS samples.

The most evident criteria for the samples activity was the half-conversion time, $\tau_{1 / 2}$, i.e. a period of time from experiment beginning up to the moment, when $\mathrm{C}_{\mathrm{O}_{3}}^{f}$ became equal to $0.5 \mathrm{C}_{\mathrm{O}_{3}}^{i n}$, at which point an experiment was stopped. $\tau_{1 / 2}$ was used for calculation of a reaction rate constant for ozone decomposition, $k_{1 / 2}$ :

$$
k_{1 / 2}=\frac{0.69}{\tau_{1 / 2}}\left[\mathrm{~s}^{-1}\right] .
$$



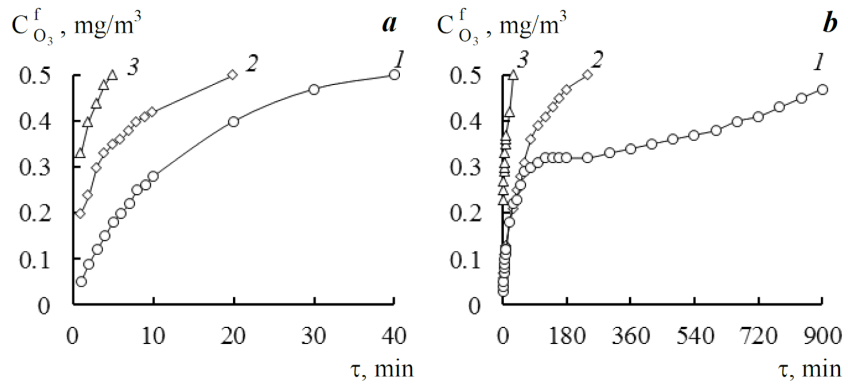

Fig. 3. Time dependences of $\mathrm{C}_{\mathrm{O}_{3}}^{f}$ for IS (a) and IIS (b) samples calcined at $200{ }^{\circ} \mathrm{C}$ (1), $300{ }^{\circ} \mathrm{C}$ (2), and $500^{\circ} \mathrm{C}(3)$.

The higher $\tau_{1 / 2}$ is, and the lower $k_{1 / 2}$ is, the more active the catalyst is and the larger the amount of ozone is that entered the reaction $\left(Q_{1 / 2}\right.$, moles of $\left.\mathrm{O}_{3}\right)$. Reaction rates at the beginning of the testing $\left(\mathrm{W}_{\text {in }}\right)$ are similar for IS and IIS samples (Table II).

\section{TABLE II}

Kinetic and stoichiometric parameters of the reaction of ozone decomposition with iron oxide samples $\left(C_{\mathrm{O}_{3}}^{i n}=\right.$ $1 \mathrm{mg} / \mathrm{m}^{3}$ )

\begin{tabular}{c|c|c|c|c}
\hline \hline Sample & $\begin{array}{c}W_{i n} \times 10^{10} \\
{[\mathrm{~mol} /(\mathrm{g} \mathrm{s})]}\end{array}$ & $\tau_{1 / 2}[\mathrm{~min}]$ & $\begin{array}{c}k_{1 / 2} \times 10^{4} \\
{\left[\mathrm{~s}^{-1}\right]}\end{array}$ & $\begin{array}{c}Q_{1 / 2} \times 10^{7} \\
{\left[\mathrm{~mol} \mathrm{O}_{3}\right]}\end{array}$ \\
\hline IS-200 & 6.65 & 40 & 2.9 & 4.2 \\
IS-300 & 5.60 & 20 & 5.7 & 1.9 \\
IS-500 & 4.69 & 5 & 23.0 & 0.4 \\
\hline IIS-200 & 6.79 & $>900$ & - & 114.0 \\
IIS-300 & 6.65 & 240 & 0.5 & 26.7 \\
IIS-500 & 5.39 & 30 & 3.8 & 2.9
\end{tabular}

It should be noted that all IS samples rapidly lost their activity with the increase in their calcination temperature from 200 to $500{ }^{\circ} \mathrm{C}\left(\tau_{1 / 2}\right.$ decreases from 40 to $5 \mathrm{~min})$. IIS samples are much more active in the reaction of ozone decomposition: their $\tau_{1 / 2}$ and their $Q_{1 / 2}$ values are several times higher than those for IS samples. IIS-200 sample shows a near steady-state mode of reaction for an extended period, with a final ozone concentration not higher than $0.32 \mathrm{mg} / \mathrm{m}^{3}$. However, other IIS samples, similarly to IS samples, lost their activity after treatment at higher calcination temperatures. The kinetic data demonstrate the dependence of activity of IS and IIS samples on both the nature of iron(III) precursors and calcination temperature. These conditions predetermine phase compositions of the samples. On the basis of the data presented in Tables I and II, we conclude that the IIS-200 and IIS-300 samples containing only $\gamma-\mathrm{Fe}_{2} \mathrm{O}_{3}$ phase are more active in the reaction of ozone decomposition than samples containing $\alpha$ - $\mathrm{Fe}_{2} \mathrm{O}_{3}$ phase - either as a predominant phase, as in polyphase IS-200 and IS300 samples, or as the only phase, as in the monophase IIS-500 sample, or as a major phase with $\gamma-\mathrm{Fe}_{2} \mathrm{O}_{3}$ as an admixture (IS-500).

\section{Conclusions}

For different forms of iron oxides synthesized from $\mathrm{FeCl}_{3}-\mathrm{FeSO}_{4}$ and $\mathrm{Fe}_{2}\left(\mathrm{SO}_{4}\right)_{3}-\mathrm{FeSO}_{4}$ salt mixtures, the phase composition and size of crystallites depend on the nature of iron(III) precursors and calcination temperature. Calcination of $\mathrm{FeCl}_{3}-\mathrm{FeSO}_{4}$ salts at 200 and $300^{\circ} \mathrm{C}$ resulted in the formation of samples containing $\alpha-\mathrm{Fe}_{2} \mathrm{O}_{3}$, $\gamma-\mathrm{Fe}_{2} \mathrm{O}_{3}, \mathrm{Fe}_{3} \mathrm{O}_{4}$, and $\alpha-\mathrm{FeO}(\mathrm{OH})$ phases, whereas thermal treatment at $500{ }^{\circ} \mathrm{C}$ led to the prevalence of $\alpha-\mathrm{Fe}_{2} \mathrm{O}_{3}$ phase with $\gamma-\mathrm{Fe}_{2} \mathrm{O}_{3}$ as an admixture. Conversely, calcination of $\mathrm{Fe}_{2}\left(\mathrm{SO}_{4}\right)_{3}-\mathrm{FeSO}_{4}$ salts at 200 and $300^{\circ} \mathrm{C}$, resulted in monophase samples containing only $\gamma-\mathrm{Fe}_{2} \mathrm{O}_{3}$, whereas calcination at $500^{\circ} \mathrm{C}$ resulted in the quantitative transformation of $\gamma-\mathrm{Fe}_{2} \mathrm{O}_{3}$ into $\alpha-\mathrm{Fe}_{2} \mathrm{O}_{3}$. The samples were tested in the reaction of ozone decomposition, and the results suggest that the activity of samples composed of $\gamma-\mathrm{Fe}_{2} \mathrm{O}_{3}$ (maghemite) is several times higher than the activity of predominantly $\alpha$ - $\mathrm{Fe}_{2} \mathrm{O}_{3}$-containing samples.

\section{References}

[1] X. Zheng, Y. Jiao, F. Chai, F. Qua, A. Umar, X. Wu, J. Coll. Interf. Sci. 457, 345 (2015).

[2] M. Taseidifar, A. Khataee, B. Vahid, S. Khorram, S.W. Joo, J. Mol. Catal. A Chem. 404-405, 218 (2016).

[3] J.-S. Park, H. Choi, J. Cho, Water Res. 34, 2285 (2004).

[4] T. Zhang, C. Li, J. Ma, H. Tian, Z. Qiang, Appl. Catal. B Environ. 82, 131 (2008).

[5] T. Zhang, J. Lu, J. Ma, Z. Qiang, Water Res. 42, 1563 (2008).

[6] T. Zhang, J. Ma, J. Mol. Catal. A Chem. 279, 82 (2008).

[7] M. Munoz, Z.M. Pedro, J.A. Casas, J.J. Rodriguez, Appl. Catal. B Environ. 176-177, 249 (2015).

[8] B.I. Kharisov, H. Rasika, H.V. Dias, O.V. Kharissova, Arab. J. Chem. (2014).

[9] A. Šaric, S. Music, K. Nomura, S. Popovic, J. Mol. Struct. 480-481, 633 (1999).

[10] S. Musić, A. Šarić, S. Popović, J. Mol. Struct. 410411, 153 (1997).

[11] S. Ni, D. He, X. Yang, T. Li, J. Alloys Comp. 509, L305 (2011).

[12] L. Hou, H. Zhang, L. Wang, L. Chen, Chem. Eng. J. 229, 577 (2013).

[13] M. Minella, G. Marchetti, E. Laurentiis, M. Malandrino, V. Maurino, C. Minero, D. Vione, K. Hann, Appl. Catal. B Environ. 154-155, 102 (2014).

[14] S.T. Oyama, Catal. Rev. Sci. Eng. 42, 279 (2000).

[15] T. Rakitskaya, A. Truba, A. Ennan, V. Volkova, Nanoscale Res. Lett. 10, 473 (2015).

[16] T.L. Rakitskaya, A.S. Truba, A.A. Ennan, V.Y. Volkova, Adv. Mater. Res. 1138, 7 (2016).

[17] J. Rodriguez-Carvajal, T. Roisnel, Commission for Powder Diffraction, International Union of Crystallography, Newsletter, 1998. 
[18] S.-C. Yu, J.-S. Lee, S.-F. Tung, C.-L. Lan, J. Geolog. Soc. China 42, 349 (1999).

[19] H.-S. Shin, J. Kor. Ceram. Soc. 35, 1113 (1998).

[20] J.P. Wright, J.P. Attfield, P.G. Radaelli, Phys. Rev. B 66, 214422 (2002).

[21] J.L. Hazemann, J.F. Berar, A. Manceau, Mater. Sci. Forum 79, 821 (1991).

[22] G. Gnanaprakash, S. Mahadevan, T. Jayakumar, Mater. Chem. Phys. 109, 168 (2007).
[23] Y.H. Chen, J. Alloys Comp. 553, 194 (2013).

[24] M. Gotič, G. Koščec, S. Musič, J. Mol. Struct. 924926, 347 (2009).

[25] E. Darezereshki, Mater. Lett. 64, 1471 (2010).

[26] W.-Q. Xu, Y.-G. Yin, G.-Y. Liz, S. Chen, Appl. Catal. A Gen. 89, 117 (1992). 